\title{
Examination of the Views of High School Teachers and Students with Regard to Discipline Perception and Discipline Problems
}

\author{
Fatma Sadik ${ }^{1}$, Onur Yalcin ${ }^{1}$ \\ ${ }^{1}$ Çukurova University, Faculty of Education, Turkey \\ Correspondence: Fatma Sadik, Çukurova University, Faculty of Education, Turkey. \\ Received: October 19, 2017 \\ Accepted: January 21, $2018 \quad$ Online Published: January 27, 2018 \\ doi:10.11114/jets.v6i2.2715 \\ URL: https://doi.org/10.11114/jets.v6i2.2715
}

\begin{abstract}
This research is a qualitative study comparatively examining the views of high school teachers and students related to discipline perception and discipline problems. The study has been realized at a vocational school during the $2014 / 2015$ school term. Maximum diversity and criterion sampling methods have been followed for the formation of the study groups with 18 teachers and 16 students. The data collected through semi-structured interview forms has been evaluated by content analysis. As a result of the study, it has been observed that the teachers define discipline as a wholistic system, self-control and providing the necessary learning environment, while the students define it as self-control, obeying the rules and respect. The participating teachers, who agreed on the idea that discipline does not mean bullying or passivizing the individuals, described rudeness, lack of interest in the lesson and misbehavior as disciplinary problems. According to the teachers, not fulfilling the responsibilities and rudeness; according to the students, preventing the course from running and not being interested in the course are the most experienced discipline problems at their respective schools. Pursuant to the acquired results, the students differ from the teachers by thinkink that behavior such as not obeying the directives, using hazardous items and harming the environment/objects are the most common problems.
\end{abstract}

Keywords: discipline, high school, teacher, student

\section{Introducation}

The classroom is a social group established by the the students with their different lives, feelings, cultures, values, behaviors and habits. In an environment with so much diversity, the realization of common goals and expectations is related to the creation of a positive pyscho-social communication environment in the classroom, the formation of an effective and efficient learning environment, the fortification of positive behavior and the change of negative behavior (Gökyer \& Doğan, 2016). Providing classroom discipline is an important factor for realizing all of these (Kiptala, Okero \& Kipruto, 2011; Moreno, Cervelló\&Martínez Galindo, 2007). The aim of discipline is to create physical, emotional and social safety, enabling the individuals who are part of the social system to realize themselves and to protect the rights of people who are uncooperative, aggressive or exposed from other preventing reactions (Bear, 2005; Humphreys, 1998). Discipline in the classroom enables the learning activities as planned, using the time effectively and provides stability for behavior management (Kayabaşı \& Cemaloğlu, 2007). However, in traditional societies discipline is perceived as martial law, authority, compliance, rules and demonstrating behavior according to the directives (Humphreys, 1998; Haroun \& O'Hanlon, 1997; Kiptala, Okero \& Kipruto, 2011). Doyle (2006) and Humphreys (1998) stated that this perception causes excessively controlled behavior such as silence, passivism, obeying all rules and forbearance in individuals; discipline is not only the rules to be obeyed and the maintenance of the system you live in. Adhering to this idea, Yavuzer (2003) emphasizes that discipline is an educational process and its aim is to provide the individual with orientation in this environment and to sustain positive behavior by developing a feeling of responsibility. In this context, classroom discipline is a process of preparing the necessary conditions relevant to the learning aims, the arrangement of teaching/learning activities, interaction in the classroom and the establishment of rules in the classroom. (Demir, 2011; Lewis, Romi, Qui \& Katz, 2005; Sarpkaya, 2007). In this process, the task of the teacher is to identify his/her students and to create a relevant classroom environment which presents the opportunity of knowing themselves and helping them to control themselves (Charles, 2005; Jones, 1981; Marlow \& Page, 1998). In the same way, the responsibilities of the students are endeavoring for trying to know each other and themselves, to respect each other, to establish a positive/structured communication with their environment, internalizing the social as well as other rules and developing their affective skills (Rogers, 1983; Tunç, Yıldız \& Doğan, 2015; Vitto, 2003). 
Differing perceptions of these tasks and responsibilities by the teachers and the students or not realizing them at all may cause many problems for classroom discipline. For this reason, the students and the teachers sharing this common environment should have a collective perception and understanding what discipline is and which behavior is qualified as a discipline problem. Solving of problems related to discipline, understanding the possible reasons, taking the necessary action and solving the problematic behavior in a relevant way is all related to this (Manning \& Bucher, 2007).In other cases, situations such as an uncertainty in the classroom environment, behaviors affecting the order negatively and experiencing teaching problems will increase (Helvac1, 2010). According to related literature, it can be be seen that the subject has been examinded from the teachers' point of view and behavior has been defined as a discipline problem from the teachers' angle (Aygün 2013; Çerçi, 2009; Çetin, 2013; Ding, Li, Li \& Kulm, 2008; Erol, 2014; Güner, 2009; Kara, 2008; Lewis, 2001; Sadık, 2002; Sadık \& Aslan, 2015; Sağanak, 2008; Tartwijk, Brok, Veldman \& Wubbels, 2009; Tomal, 2001). The gained results indicate that teachers mostly perceive behavior affecting the teaching/learning process in the classroom (not following the course, not bringing educational materials to the school, not realizing the assigned tasks, being disrespectful to the teacher, walking around in the classroom, interrupting the course, making noise, etc.) and behavior negatively affecting the relationships in the classroom (talking with a loud voice, polluting the classroom, being rude, interrupting friends, telling a lie, etc.) as discipline problems (Çetin, 2013, Dağlı \& Baysal, 2011; Demir, 2011; DeSouza \& Ribeiro, 2005; Ekici \& Ekici, 2014; Gökyer \& Doğan, 2016; Infantino \& Little,2005; Kuzu, 2007; Mitchell \& Bradshaw, 2013; Öz \& Sadık, 2015; Stephenson, Linfoot \& Martin, 2000). Studies examining the views of students about discipline problems (Döker, 2006, İnce, 2011; Lewis, 2001; Polat, Kaya \& Akdağ, 2013; Rahimi \& Hosseini, 2012; Sarpkaya, 2007) and comparative studies on teacher/student views (Atıc1 \&Çekici, 2009; Lewis, Romi, Qui \& Katz, 2005) are relatively limited.

Taking the subject from the views of the teachers as well as the students into account is undoubtfully important for determining the attitudes of the two parties towards this subject. However, this situation can result in being one-sided in determining discipline problems and their causes as well as for producing solution proposals. According to Mainhard, Brekelmans and Wubbels (2011), the perception of individuals about discipline can cause them to state the behavior causing discipline problems and their causes. Manning and Bucher (2007), following the same thought, state that many factors such as developmental conditions, the psycho-social environment, genetic dispositions, and instinctive situations affect the perception of discipline. This situation especially plays a great role at high schools. Because high school students in their adolescent period with developing conditions are in a rapidly changing period (Siyez, 2009). The students can show reactions to the perception of behavior or situations which are not a problem for them as being without discipline or being problematic during this period where they experience rapid changes not only physically but also emotionally Also, situations or enforcements they will witness later can cause them to exhibit a more destructive behavior (Sarpkaya, 2007; Watkins \& Wagner, 2000). In the classrooms where the students and the teachers do not have a common understanding about the aim and requirements of discipline; disacords or conflicts because of being misunderstood is inevitable, making effective classroom management and behavioral management more difficult (Edwards \& Mullis, 2003; Öz \& Sadık, 2015). Related to these reasons, research is necessary examining the comparison of discipline perceptions of teachers and students and which behavior is qualified as a discipline problem by them. This study which examines the views of students and teachers simultaneously is important in regard of being a mirror between groups who share the environment, and for showing how they evaluate the in-classroom behavior. Answers to the questions below are tried to be found with this goal:

1. How are the perceptions of teachers and students related to what discipline is?

2. How are the perceptions of teacher and students related to what discipline is not?

3. Which behavior is qualified as a discipline problem by teachers and students?

4. Which discipline problems are experienced mostly in their schools/classroom according to the students as well as the teachers?

\section{Method}

\subsection{Research Design}

The study is a phenomenology research determining the views of high school students and teachers about discipline problems and their perceptions of discipline. Phenomenology research focuses on the facts which we are aware of but do not have a deep and detailed understanding for. (Johnson \& Christensen, 2004). Phenomenology cannot present concrete and generalized results relevant to the nature of qualitative research. But it is important as presenting examples, explanations and experiences which will help us to learn and understand facts (Cropley, 2002). The basic fact which is examined in this study is discipline. 


\subsection{Study Groups}

It is necessary to work with people who will be able to reflect facts or experience them according to the research in phenomenology studies (Patton, 2002). In this context, this study has been carried out with teachers and students as participants. Criterion sampling and maximum variation samplingmethods have been used for the determination of the participants.

\subsubsection{Teacher Study Group}

The group is created of 18 teachers working at a vocational high school in the Seyhan District of Adana during the 2014/2015 school term. The teachers work with all classes of the grades 9-12 (criterion), come from different disciplines and have been working for different periods (maximum variation). Eight of the participating teachers were male, 10 were female. Their job experience ranges between 5-10 and 10-15 years; they have been working in the fields of Physics (f:2), Chemistry (f:2), Biology (f:1), English (f:3), Geography (f:2), Turkish Language and Literature (f:4), as well as Mathematics (f:3). Most of the teachers are graduates of educational faculties (f:12), four teachers have a master's degree.

\subsubsection{Student Study Group}

It consists of 16 students, two male and two female students from all grades (criterion) where the teachers who have been interviewed teach. The fathers and mothers of the students mostly are graduates of elementary and secondary school. Their mothers are housewives; the fathers are self-employed or workers. The parents of the students have at least three children and live together. Four of the students work out of the school hours and the families have a low income (1000-1500 TL). Their academic success is at a low and middle level.

\subsection{Data Collection Tools}

The data has been collected with semi-structured interview forms which were developed simultaneously for the teachers and students according to expert views from the literature by the researchers. A pilot implementation was performed with two high school teachers and two high school students to verify the understandability of the questions and to discover any problems. The interviews have been done in the guidance room; they have been completed in 20-25 minutes. The interviews have been recorded with a sound recorder upon the approval of the participants.

\subsection{Data Analysis}

The content analysis technique has been used for the evaluation of the gathered data. Firstly, interview records were written down, a total of 32 pages of text has been compiled as data. A general framework has been followed during the coding; the data was examined with an inductive understanding. During the coding process, the researchers did the coding independently and the consensus between the coders was found to be .82 through the Miles \& Huberman formulation (1994, p.64). In case of different coding ideas, the researchers decided jointly what the code will be. Two researchers established the themes; in the last step, the data was arranged in tables. In the presentation of the findings, quotations came directly from the ideas of the participants; during this process codes were used to define the teacher or student whose quotations have been taken (T1M, states that the first interview of a teacher has been made with a male; S1M9 states that the first interview of a student has been made with a male from the $9^{\text {th }}$ grade).

\section{Results}

\subsection{The Perceptions of Teachers and Students about What Discipline Is}

Example answers of the participants as well as the themes and codes to the question "What do you understand when discipline is mentioned, how do you define it" are summarized in Table 1. 
Table 1. Perceptions related to what discipline is

\begin{tabular}{|c|c|c|c|c|}
\hline Theme & Code & Teacher & Student & $\mathrm{N}$ \\
\hline \multirow[t]{9}{*}{ Self-control } & To control the feelings & 3 & 1 & \multirow{9}{*}{29} \\
\hline & To control the behavior & 3 & 3 & \\
\hline & To fulfill the responsibilities & 2 & 5 & \\
\hline & To keep your promises & 2 & 3 & \\
\hline & To behave consistently & 1 & 2 & \\
\hline & To know rights and responsibilities & 1 & 1 & \\
\hline & To behave according to the environment you live in & 1 & 5 & \\
\hline & To know how to behave in a social environment & - & 1 & \\
\hline & Total & 13 & 16 & \\
\hline \multirow[t]{16}{*}{ System } & A harmony of all variables such as teachers, students, materials, environment etc. & 3 & - & \multirow{16}{*}{21} \\
\hline & Continuation of educational activities & 3 & - & \\
\hline & Reaching the target of the course & 2 & - & \\
\hline & Not preventing the teaching process & 2 & - & \\
\hline & To be able to get forward in the direction of the aims & 2 & - & \\
\hline & Way to success & 2 & - & \\
\hline & Cooperation/being able to work together & 2 & - & \\
\hline & Applying teaching activities as they are required to be & 1 & - & \\
\hline & To realize the obligations & - & 1 & \\
\hline & To make everything proceed regularly & - & 1 & \\
\hline & Life-style & - & 1 & \\
\hline & To move together & - & 1 & \\
\hline & To act according to the plan & - & 1 & \\
\hline & To control the process & - & 1 & \\
\hline & To know the aim of the task & - & 1 & \\
\hline & Total & 14 & 7 & \\
\hline \multirow{7}{*}{$\begin{array}{l}\text { Rules/obeying } \\
\text { the rules }\end{array}$} & All rules constituting the educational system reach their aim & 2 & 1 & \multirow{7}{*}{21} \\
\hline & To make the students obey the school/the classroom rules & 2 & 11 & \\
\hline & To obey social rules & 1 & 1 & \\
\hline & The rules to be obeyed by everybody living in the same environment & 1 & - & \\
\hline & Rules which are applied to create a structured environment & 1 & - & \\
\hline & Implementations which make the individual behave in a relevant way in the society & 1 & - & \\
\hline & Total & 8 & 13 & \\
\hline \multirow{7}{*}{$\begin{array}{l}\text { Respect } \\
\text { towards you } \\
\text { and } \\
\text { to yourself }\end{array}$} & To act out rights and responsibilities without harming others & 2 & - & \multirow{7}{*}{21} \\
\hline & To respect each other & 2 & 6 & \\
\hline & To show mutual respect & 2 & 1 & \\
\hline & To respect yourself & 1 & 1 & \\
\hline & To act by thinking of others & 1 & 1 & \\
\hline & To behave well towards other living creatures & - & 1 & \\
\hline & Total & 8 & 13 & \\
\hline & To protect the structure which makes the educational system work well & 2 & - & \\
\hline mechanism & To protect peace & 1 & - & \\
\hline & To provide safety & 1 & - & \\
\hline & To protect rights & 1 & - & \\
\hline & To protect human values & 1 & - & \\
\hline & To meet the needs of the individual in the environment he lives in & 1 & - & 16 \\
\hline & To claim one's right/to ask about the requirements & 1 & 1 & \\
\hline & To solve the problem & - & 1 & \\
\hline & To prevent irrelevant behavior & - & 1 & \\
\hline & To express feelings and ideas & - & 1 & \\
\hline & To protect the activities of life/to live like a human being & - & 1 & \\
\hline & To make the individual protect his democratic rights in the environment he lives in & - & 1 & \\
\hline & Total & 8 & 8 & \\
\hline To provide a & To orient the students towards a goal & 2 & - & \\
\hline relevant & To manage the teaching process & 2 & - & \\
\hline teaching & To establish the necessary conditions for effective teaching & 2 & - & \\
\hline environment/ & To take the actions which will make the students behave positively & 1 & - & 10 \\
\hline regularity & To arrange student's behavior according to the environment and time & 1 & - & \\
\hline & Motivation, finding sources of interest and promoting these & 1 & - & \\
\hline & To create an environment which protects individual rights and freedom & 1 & - & \\
\hline & Total & 10 & - & \\
\hline Positive & To be successful & - & 1 & \\
\hline personality & To be ethical & - & 1 & \\
\hline features & To be benelovent & - & 1 & \\
\hline & To be strong-minded & - & 1 & \\
\hline & To be honest & - & 1 & \\
\hline & To be diligent & - & 1 & 8 \\
\hline & To be hardworking & - & 1 & \\
\hline & To be principled & - & 1 & \\
\hline & Total & - & 8 & \\
\hline Education & Being social/the socialization process & 1 & - & \\
\hline & The learning process & 1 & - & \\
\hline & Ethical education & 1 & - & \\
\hline & Formation of conscience & 1 & - & 6 \\
\hline & Process of gaining self-control & 1 & - & \\
\hline & Developing yourself & - & 1 & \\
\hline & Total & 5 & 1 & \\
\hline
\end{tabular}


As seen in Table 1, the teachers defined discipline mostly as a system (f:14), self-control (f:13) to provide the necessary teaching environment/order (f:10); followed by obeying the rules (f:8), respect for yourself and others (f:8), a protection mechanism (f:8) and education (f:5). The participating teachers emphazied the harmony of the variables such as teachers, students, materials, classroom settings etc. (f:3) and the continuing of the educational activities (f:3) under the system theme. Reaching the target of the course, being able to get ahaed in the direction of the goals, a road leading to success, being able to work together, and applying the teaching activities as required are following. For example: T6F stated her idea as "...Discipline is achieving and realizing the teaching goals completely and on time", while T4F stated her idea as "...to provide harmony in the classroom and managing the materials, teaching methods and students in accordance with each other while employing the teaching activities in the classroom." The teachers who stated that discipline means self-control explained this as controlling feelings (f:3) and behavior (f:3). For example: T11F stated her idea as "...to arrange our behavior according to the time and location. So, we are oriented towards a target", whereas $\mathrm{T} 5 \mathrm{~F}$ explaned it as "to realize whatever we planned on that day, despite all obstacles". Two quotation examples from other teachers' explanations are given below:

“....it means individuals behave and request their rights by knowing the responsibilities of the educational environment" T14M

"Discipline is a process of gaining self-control for the students. To completely provide conscience and ethics as well as realizing the promises related to this in a timely fashion" T16M

Ten teachers who perceived the relevant teaching environment as discipline generally emphasized the orientation of the students towards a target (f:2), managing the teaching process (f:2) and establishing the required conditions for effective teaching (f:2). The teachers whose discipline perception is obeying the rules see rules as an instrument for reaching the target. For example: T10M stated his ideas as "...discipline means all actions to make the students obeying the classroom rules, enabling the students to behave properly" whereas T15M explaned it as "Discipline is a whole set of rules and attitudes needed for the educational environment or system to function properly". Respecting each other and yourself, a protection mechanism, providing the necessary teaching environment and educational process are further definitions of the teachers related to discipline. Below are sample quotations of the teachers' ideas:

"Discipline is obeying the actual social rules to preserve the social order and protecting humanistic values while accomplishing our freedom and rights." $\mathrm{T} 17 \mathrm{~F}$

"It is showing respect to the rights of other people and also to yourself. If there is respect, there is also order." T2F

"...discipline is respecting the rights to live and freedom of individuals." T5M

"It means completely using one's consciousness and ethics, accomplishing all the promises on time and acting by thinking of the person opposite of you." T16M

The students defined discipline as self-control (f:16), obeying the rules (f:13), as well as respecting others and yourself (f:13). According to the students, self-control mostly means accomplishing your responsibilities, behaving according to the social environment and controlling your behavior. For example: S9M11 explained it as "...discipline is the process of controlling the behavior towards the direction of the objectives", while S5M10 said "...it means doing your duties and processing everything regularly. It means living according to one's nature and environment, in other words, not changing the order you live in and keeping the harmony around alive". S11M11 explained it as "It means acting together regularly and being responsible for an aim, in other words for a significant framework". While most students who perceive discipline as rules, emphasized making the students obey the school and classroom rules, a few students mentioned social rules. The students who defined discipline as respect to themselves and others mostly stated -like the teachers- respecting the others' rights and responsibilities (f:6). In addition to this, when Table 1 has been examined, it was seen that a few students consider respecting themselves, acting by putting themselves into the others' shoes and behaving owards other creatures well within this topic. While the students who perceive discipline as a protective mechanism stated their ideas as providing a life like a human being, solving problems, being able to claim one's rights; the students who perceive discipline as a system emphasized acting according to a plan, comply with the required duties, knowing its aim. Quotation samples from the ideas of the students are given below:

\footnotetext{
"Discipline is people living according to their nature and environment, in other words not changing the existing order and protecting harmony" S5F9

"...discipline is being able to regularly act together and being responsible for a goal, in other words for a significant good. To establish democracy and to respect the other's' decisions" S11M11

"...It is an entity of actions in which the person finds him/herself in planned activities by being faithful... to protect the existing living activities. For example, allowing the plants to live or the people to freely get happy or unhappy or protesting and doing crazy things. "S13M12
} 
"To be able to act regularly within a specific framework, in other words, towards a goal, to establish democracy and enliven it." S10M1

When examining Table 1, it can be seen that the students define discipline not as a perception related to the goal of providing the relevant educational and teaching environment, but as personality features for being successful, ethical, determined, good mannered, honest, conscious, hardworking and having principles. For example, S6M10 stated his idea saying "discipline means always behaving in the same way, in other words being stable and characterful”, S9M11 explained is as "having a sympathetic behavior, protecting rights and arranging one's own consciousness" and S10M11 decribed it as "being ethical, hardworking, a person's inner and outer world to be the same, being on time, knowing his job's goal”.

\subsection{Perceptions of Teachers and Students What Discipline Is Not}

Themes and codes taken from the examples and explanations of teachers and students of what discipline is not are summarized in Table 2.

Table 2. Perceptions related to what discipline is not

\begin{tabular}{|c|c|c|c|c|}
\hline Theme & Code & Teacher & Student & $\mathrm{N}$ \\
\hline \multirow{11}{*}{ Bullying } & Forcing people to behave in a way they want & 6 & 1 & \multirow{11}{*}{32} \\
\hline & Shouting/scolding & 4 & 8 & \\
\hline & Applying physical violence/hitting & 4 & 7 & \\
\hline & Punishing & 3 & 1 & \\
\hline & Insulting & 2 & - & \\
\hline & Humiliating & 2 & - & \\
\hline & Cuasing fear & 1 & 2 & \\
\hline & Regarding everything as our own possesion & 1 & - & \\
\hline & Mobbing & 1 & 1 & \\
\hline & Using force & - & 8 & \\
\hline & Total & 16 & 16 & \\
\hline \multirow{10}{*}{$\begin{array}{l}\text { Being passive } \\
\text { / being passivized }\end{array}$} & Being silent about the events & 6 & 8 & \multirow{10}{*}{30} \\
\hline & Obeying the instructions & 4 & 14 & \\
\hline & Accepting everything without scrutinizing & 3 & 8 & \\
\hline & Doing everything that is wanted & 3 & - & \\
\hline & Limiting the area of actions/movements of the people & 2 & - & \\
\hline & Not looking after one's rights & 1 & 2 & \\
\hline & Behaving in control & 1 & - & \\
\hline & Working with fear & 1 & 3 & \\
\hline & Not disturbing anything & - & 1 & \\
\hline & Total & 16 & 14 & \\
\hline \multirow{7}{*}{ Martial law } & Limiting the rights and freedom & 5 & - & \multirow{7}{*}{17} \\
\hline & Applying all rules one-by-one & 2 & 2 & \\
\hline & Strict rules & 2 & 1 & \\
\hline & Making pemanent inspections & 2 & 2 & \\
\hline & Controlling the behavior of people permanently & 1 & 2 & \\
\hline & Causing others to obey the order & - & 2 & \\
\hline & Total & 12 & 5 & \\
\hline \multirow{13}{*}{$\begin{array}{l}\text { Negative } \\
\text { features }\end{array}$} & Being perfectionist & - & 2 & \multirow{13}{*}{13} \\
\hline & Egoism & - & 1 & \\
\hline & Trying to catch the teacher's attention & - & 1 & \\
\hline & Laziness & - & 1 & \\
\hline & Behaving differently (false pretence) & - & 1 & \\
\hline & Striving for approval from everyone & - & 1 & \\
\hline & Being unwary & - & 1 & \\
\hline & Behaving unthoughtfully & 1 & - & \\
\hline & Permanent speaking & - & 1 & \\
\hline & Being joyful & - & 1 & \\
\hline & Not ignoring other people & - & 1 & \\
\hline & Evaluating people according to their outer views & 1 & - & \\
\hline & Total & 2 & 11 & \\
\hline \multirow{3}{*}{ Academic success } & Realizing the duties expected from you & 2 & - & \multirow{3}{*}{11} \\
\hline & Receiving high grades for the courses & 3 & 6 & \\
\hline & Total & 5 & 6 & \\
\hline \multirow{3}{*}{ Formal order } & Exclusive sitting order & 1 & - & \multirow{3}{*}{2} \\
\hline & Making students to behave only in one way & 1 & - & \\
\hline & Total & 2 & - & \\
\hline \multirow{2}{*}{ Giving permission } & Giving permission to everything & 1 & - & \multirow[b]{2}{*}{1} \\
\hline & Total & 1 & - & \\
\hline
\end{tabular}


As seen in Table 2, most of the teachers have the same opinion that discipline is not bullying (f:16), being passive / being passivized (f:16) and martial law (f:12). The teachers emphasized forcing people to behave in a way they want (f:6), shouting/scolding (f:4), applying physical violence/hitting (f:4), punishing (f:3) within the bullying theme; followed by insulting, humiliating, causing fear, regarding everything as our own possesion and mobbing behavior. For example, T5M stated his idea about bullying as "...Discipline does not mean making people obeying our own rules or making them to expect the same things derived from our upbringing", T15M explained this subject as "the usurpation of human rights and ignoring them according to our wishes and order cannot be discipline". Two further quotations from other teachers are given below:

"...it is not a process achieved with awards and punishment. Although tried to be achieved in this way at first, these processes should be made with self-checks.” T16M

“...discipline is not physical punishment and applying punishment, shouting and arranging an order by scaring the person through it.” $\mathrm{T} 17 \mathrm{M}$

The teachers who stated that discipline is not being passive/passivized stated their ideas as being silent about the events (f:6), obeying the instructions (f:4), accepting everything without scrutinizing (f:3), doing everything that is wanted (f:3) and limiting the areas of actions/movements of the people (f:2). In this context, T5M stated his idea saying "Discipline is not scolding the students, making them sit in order, evaluating them according to their outer views, or making them obey our rules.", T15M stated his idea as "...discipline is not making a job by causing fear, or defending our rights by being quiet", and T17M said "Discipline is not accepting instructions, being quiet or obeying the instructions". The teachers who stated that discipline is not martial law (f:12) emphasized limiting the rights and freedom (f:5), applying all rules one-by-one (f:2), strict rules (f:2) and making permanent inspections (f:2). For example, while T1M is stating his ideas as "...discipline is not regarding everything as our possesion. We want to be the god of everything and want to be like the father and mother of them. A student is not a belonging who worships everything...children cannot be limited in this way", T15M explained his idea as "... a situation where human rights are absent cannot be discipline”. As seen in Table 2, five teachers mentioned that realizing the duty expected from you and receiving high grades for the courses are not discipline and two teachers stated that discipline is not the formal order of the classroom environment. Quotations from the explanations of the teachers are given below:

“...discipline is not realizing every duty well or obeying educational outcomes by doing everything as being told. Wearing uniforms, respect for the teacher and behaving homogeneous works in education but makes the student single-typed. It makes the student dull. It diminishes the individuality." T1M

“...discipline is not being envy of others, being successful with passion and arranging an order or being systematic." $\mathrm{T} 11 \mathrm{~F}$

The explanations of the students related to what discipline is not solely concentrate on bullying (f:16), themes of being passive/passivized (f:14), negative personality features (f:11), academic success (f:6) and martial law (f:5). The students defined bullying as shouting/scolding (f:8), using force (f:8) and applying physical violence/hitting (f:7). For example, S14M12 explained this subject as "...discipline is not forcing someone to accept or realize something by demonstrating force", S5F10 said "...discipline is not achieving something through fear or violence" and S3M9 told that "Discipline is not adapting to the necessary by force". The students who stated that discipline is not passivizing the individuals or behaving passively described this situation as obeying the instructions (f:14) accepting everything without scrutinizing (f:8), being silent about the events (f:8) and working with causing fear (f:3). S8M10 explained this subject as "accepting everything without any scrutinity and applying it is not discipline" and S13M11 stated his idea as "not thinking, accepting everything, and doing everything without adding any individuality cannot be discipline". The students who underlined that discipline is not martial law mostly emphasized applying all rules one-by-one (f:2), making permanent inspections (f:2), and controlling the behavior of the people permanently (f:2). Quotations are given below:

“...discipline is not ignoring us. Permanent inspections, being in order like a soldier and applying everything without distinction cannot be accepted." S1M9

"Discipline is not ignoring the people around you. It is also not accepting all the rules. We do not always have to be in harmony." S8M10

"Being accepted by everyone, doing everything what is told or orienting people towards the order by force is not discipline." S3M9

When examining Table 2, it can be seen that some students emphasize negative personality features (f:11). In this context, being perfectionistic, egoism, behaving different (false pretence), and being joyful have been mentioned, while six students stated that realizing the duties expected from you or receiving high grades for the courses do not mean being disciplined. For example, while S6M10 stated his idea as "being antisocial, or protecting your advantages only to be 
successful is not discipline”, S9M11 stated his idea as “...it is not being perfectionistic, being seen as permanently hardworking, working on details or doing a job, accepting everything without scrutinity, being excessively hardworking or winning in every exam" and S12F11 explained it as "...being lazy and quietly accepting everything, doing everything without adding any individuality is not discipline”.

\subsection{Teacher and Student Ideas Related to Behavior Determined to Be Discipline Problems}

Behavior which has been qualified as discipline problems by teachers and students are given in Table 3.

Table 3. Behaviors which are discipline problems

\begin{tabular}{|c|c|c|c|c|}
\hline Theme & Code & Tea. & Stu. & $\mathrm{N}$ \\
\hline \multirow{16}{*}{ Rudeness } & Interrupting someone else speaking & 7 & 2 & \multirow{16}{*}{31} \\
\hline & Telling a lie & 6 & 3 & \\
\hline & Swearing & 5 & 11 & \\
\hline & Taking others' belongings without any permission & 4 & 4 & \\
\hline & Making complaints about friends & 4 & 4 & \\
\hline & Mocking & 2 & 4 & \\
\hline & Insulting & 2 & - & \\
\hline & Not keeping promises & 1 & - & \\
\hline & $\begin{array}{l}\text { Being disrespectful (Despising others, not regarding others, behavior with } \\
\text { sexual content) }\end{array}$ & 1 & 13 & \\
\hline & Disrespectful behaviors towards the teacher (despising, ignoring, etc.) & - & 5 & \\
\hline & Making strange noise (Shouting, yelling, etc.) & - & 3 & \\
\hline & Egoism & - & 2 & \\
\hline & Priggery & - & 1 & \\
\hline & Unthoughtful behavior & - & 1 & \\
\hline & Denying one's own behavior & - & 1 & \\
\hline & Total & 16 & 15 & \\
\hline \multirow{5}{*}{$\begin{array}{l}\text { Being uninterested in } \\
\text { the course }\end{array}$} & Being interested in things outside of the course (mobile phone) & 9 & 6 & \multirow{5}{*}{23} \\
\hline & Not following the lesson & 5 & - & \\
\hline & Sleeping during the course & 2 & 3 & \\
\hline & Not participating in the course & - & 2 & \\
\hline & Total & 14 & 9 & \\
\hline \multirow{9}{*}{ Preventing the course } & Going in or out during the course & 6 & - & \multirow{9}{*}{22} \\
\hline & Making noise & 4 & 4 & \\
\hline & Asking questions not related to the course & 3 & 1 & \\
\hline & Interrupting the others (through speaking) & 3 & - & \\
\hline & Being late for the course & 1 & - & \\
\hline & Changing place during the course & 1 & 3 & \\
\hline & Eating/drinking something during the course & - & 1 & \\
\hline & Leaving the classroom without permission & - & 1 & \\
\hline & Total & 14 & 8 & \\
\hline \multirow{5}{*}{$\begin{array}{l}\text { Not realizing the } \\
\text { responsibilities }\end{array}$} & Not bringing the school materials to school & 9 & 7 & \multirow{5}{*}{18} \\
\hline & Not taking responsibility & 4 & 1 & \\
\hline & Realizing the duties only randomly & 3 & 1 & \\
\hline & Not taking notes during the lesson/not doing homework & 2 & - & \\
\hline & Total & 10 & 8 & \\
\hline \multirow[t]{6}{*}{ Bullying } & Starting a fight/fighting & 4 & 6 & \multirow{6}{*}{15} \\
\hline & Hitting/attacking others & 2 & 1 & \\
\hline & Racketeering & 2 & - & \\
\hline & Building a gang & 1 & 1 & \\
\hline & Demonstrating force & - & 1 & \\
\hline & Total & 6 & 9 & \\
\hline \multirow{6}{*}{$\begin{array}{l}\text { Harming the } \\
\text { environment/materials }\end{array}$} & Drawing, scribbling on the tables/desks & 3 & 6 & \multirow{6}{*}{14} \\
\hline & Writing something on the school walls (political or sexual content) & 2 & 2 & \\
\hline & Vitiating the classroom (spitting on the ground, throwing away trash) & 2 & 2 & \\
\hline & Breaking the windows & 1 & 2 & \\
\hline & Destroying the educational equipment & - & 1 & \\
\hline & Total & 5 & 9 & \\
\hline \multirow{3}{*}{$\begin{array}{l}\text { Not obeying the } \\
\text { directives }\end{array}$} & Not obeying the school rules (being in order, participating in ceremonies.) & 6 & 2 & \multirow{3}{*}{11} \\
\hline & Untidiness of appearance (hair, beard...) & 1 & 3 & \\
\hline & Total & 6 & 5 & \\
\hline \multirow[t]{3}{*}{ Using harmful drugs } & Using drugs & 1 & 1 & \multirow[t]{3}{*}{4} \\
\hline & Smoking & 1 & 2 & \\
\hline & Total & 2 & 2 & \\
\hline
\end{tabular}


As seen in Table 3, the teachers qualify rudeness (f:16), being uninterested in the course (f:14) and preventing the course (f:14) as a discipline problem. Not realizing one's responsibilities (f:10), bullying (f:6), harming the environment/materials (f:5), behavior against the directives (f:6) follow these. The behavior the teachers mostly emphasized under the rudeness theme are interrupting (f:7), telling a lie (f:6) and swearing (f:5); some teachers mentioned taking others' belongings without permission, complaining, giving a nickname and insulting. Quotations from some of the teachers' explanations are given below:

"The students behave according to their advantages; for example they tell fake stories about teachers, these lies cause tension with his/her own friends and in the classroom" $\mathrm{T} 7 \mathrm{~F}$

"...You ask the students -who is speaking-, no reply. But when you tell them: I will send you to the discipline commission, they tell and they sneak each other, this causes incidents and discussion and all course order ends." T8F

"They do not listen to anybody in the community or each other, they only talk, this causes great noise and understanding anything becomes harder" $\mathrm{T} 13 \mathrm{~F}$

"While giving permission to a student to speak, others speak without permissiom; they try to become dominant, then the understanding of anything gets harder" T14E

“...swearing anywhere and anytime, like normal speech; I hate this situation, this naturally causes communication problems between me and the students. There are also lies." $\mathrm{T} 18 \mathrm{~F}$

The most emphasized behavior by the teachers who perceive being uninterested in the course as a discipline problem is being interested in mobile phones during the course (f:9), followed by not following the lesson (f:5) and sleeping during the lesson (f:2). For example, T3F stated her ideas about the problems she experienced with mobile phones as “...a student has been interested in everything but the course; continuously messaging on Facebook and sending messages to his/her friends, they even call each other's phones during the course" and anotherteacher T13F explained it as "the only thing they are interested in is phones, phones are their everything, they listen to music, share something on social media apps and telling that they have to like everything they share by shouting in the classroom". T5M explained that being uninterested extends to a point where the student does not know the lesson or the teacher "...our students even do not know the lesson, does anybody who does not know the lesson follow it, he even does not know which course is my lesson. Some of them even sleep in the classroom. When I see this, my motivation decreases. When the end of the year comes, they tell that they had been silent in the lessons and that they have to get a pass for the course" and T14M told that some students are sleeping in the classroom and this causes problems, describing the situation by saying "...there is a group always sleeping during the course. They awake in the middle of the course and tell that they want to wash their face. I do not give permission but they start discussing with me. This incident extends into the classroom. If I give permission, this becomes a bad example, if I do not, the student cause problems. This is a chain of events which I do not give any meaning".

When Table 3 is examined, going in or out during the course (f:6) and making noise (f:4) in the behavior preventing the course theme are prominent; in the theme of not realizing the responsibilities, not bringing the school materials to school (f:9), in the bullying theme fighting and in the theme harming the environment, writing something on the school walls are prominent. Not obeying the school directives and using narcotics are other discipline problems which the teachers mention. Quotation examples from the explanations of the teachers related to these behaviors are given below:

"...some of them are using drugs and because of this reason they behave improperly. Also, the seriousness of this situation is significant as they promote drugs to their friends; they should not be treated as students." T7F

“...you can find whatever you want: spitting on the ground, leaving trash in the classroom, putting their half-eaten foods under the desks, harming their friends' school bags and desks, they even once broke an air conditioner." T10M

“...I give homework about the lesson. But the homework they prepare is silly and careless... They request everything without showing any efforts, they want everything ready for them...they always hit each other, but you cannot understand whether it is a joke or not, when you interfere, they say: what have we done, when you do not interfere the case becomes complicated. Sometimes I see them taking belongings or moneyfrompassive students.” T11F

"They do not obey the starting time; they go in and out of the classroom whenever they want. When I just started the lesson, one the students tells 'Sorry, I am late but I was at the principal' or they send another student to the prinicipal. I do not believe them but there is nothing else I can do". T14M

As can be seen in Table 3, the students have the same ideas as their teachers about behavior that should be subject to discipline, they mostly emphasized rudeness (f:15), being uninterested in the lesson (f:9) and bullying (f:9). While the students mostly mentioned being disrespectful and swearing as rude behavior, the teachers emphasized bullying and being interested in mobile phones in the theme of being uninterested in the lesson and bullying. For example, S12M11 
stated "...the males always exhibit angry and fierce behavior. They do not give permission to speak to others and they disdain us. They are very rude, they always tell lies about anyting", S14M12 explained his idea as "their speaking style is so strange, their speeches are rude and full of swearing. They call each other by the names of animals; if they speak to me like this I never speak with them again" and S15F12 said "...they do not give the others an opportunity to speak and when we are uncomfortable about it, they use bad expressions such as 'do not speak' or 'shut up' as they always swear towards each other, this is normal for them". S3M9, who stated that being interested in mobile phones in the classroom is so disturbing and that tension is experienced in the classroom because of this, explained "The teacher sometimes wants their phone and discusses with them; but there are also some discussions because of the phone amongst them" and S6M10 described being uninterested in the course as "... some of our friends always sleep during the lesson. However, some of them are working. But some of them know they will still pass the course at the end of the year". Quotations about the ideas of the students are given below:

“...they are making saucy actions. Only to joke but sometimes it turns into fighting. Usually they think they are adult men, but they squeal everything to the teacher, whenever this happens a discussion starts." S1M9

“...they solve problems with lies. When the truth comes out, they start fighting; it is not important where the fight will occur, in the lesson or out of the lesson." S7M10

“...people we do not know take our pencils without asking. Then they tell us that they will bring them back the next lesson, and advise us not to cause any problem. They speak as if it is their belonging. Sometimes I see my classmate taking my course books or even my notes." S11F12

When Table 3 is examined, it can be seen that only a few students, compared with the teachers, qualify preventing the course and not fulfilling the responsibilities as a discipline problem, while more students qualify harming the belongings and environment as a discipline problem. For example, S7M10 explains the situation when there is noise in the classroom by stating: "there is always irrelevant and meaningless talking between them during the lesson. Conversations from the break continue. The teacher tries to stop them by hitting on the table but no one listens" and S13M12 stated his idea as "there is humming because of acting only according to their wishes, teaser speeches and talking loudly. While we want to follow the course, they go on chatting, sometimes they turn on music". Quotations from the ideas of the students are given below:

"Political writings and erotic pictures have been drawn on the walls of the empty classrooms. I sometimes ask how their brain works. Some of our classroom windows are broken and the school does not repair them as a punishment. As the teachers feel cold, they even do not want to enter our lessons." S1M9

“...most of our friends come to school without bringing anything. Like going to a wedding ceremony, they do not have a notebook or books. When we want them to listen to the course, incidents happen". S7E10

“...nobody obeys the school rules. First of all, the dress code and being in order. Everybody acts comfortably, everybody throws trash, and writes something on the walls, even political writings." S14M12

\subsection{Teacher and Student's Ideas about Discipline Problems Occuring the Most}

In this part, the teachers and students were asked about the discipline problems occurring the most in the classroom and at school; their explanations are summarized in Table 4. 
Table 4. Discipline problems occuring the most

\begin{tabular}{|c|c|c|c|c|}
\hline Theme & Codes & Tea. & Stu. & $\mathrm{N}$ \\
\hline \multirow{13}{*}{ Rudeness } & Interrupting others & 10 & 7 & \multirow{13}{*}{27} \\
\hline & Swearing, speaking badly & 6 & 6 & \\
\hline & Being against the teacher (not listening, disdaining, and being opposite.) & 4 & - & \\
\hline & Telling a lie & 2 & 2 & \\
\hline & Behaving arrogantly and insolent & 1 & 1 & \\
\hline & Not communicating & 1 & - & \\
\hline & Not respecting other's political ideas & - & 4 & \\
\hline & Mocking & - & 3 & \\
\hline & Taking others' belongings without permission & - & 2 & \\
\hline & Action including sexual content (arm/hand movements) & - & 2 & \\
\hline & Ignoring the differences & - & 2 & \\
\hline & Complaining about friends to the teachers & - & 1 & \\
\hline & Total & 14 & 13 & \\
\hline \multirow{9}{*}{ Preventing the lesson } & Making noise & 6 & 4 & \multirow{9}{*}{20} \\
\hline & Changing the place during the lesson & 2 & - & \\
\hline & Listening to music loudly & 2 & - & \\
\hline & Being late for the lesson & 1 & - & \\
\hline & Telephone is ringing during the lesson & 1 & - & \\
\hline & Asking and speaking permanently on subjects outside of the course & - & 6 & \\
\hline & Opening and closing the classroom doors continuously & - & 4 & \\
\hline & Changing the sitting place in the lesson & - & 1 & \\
\hline & Total & 8 & 12 & \\
\hline \multirow{3}{*}{$\begin{array}{l}\text { Not fulfilling } \\
\text { responsibilities }\end{array}$} & Not bringing the teaching materials to school (book, notebook, pencil,etc) & 8 & 4 & \multirow{3}{*}{15} \\
\hline & Not doing the homework & 2 & 3 & \\
\hline & Total & 9 & 6 & \\
\hline \multirow{4}{*}{$\begin{array}{l}\text { Being uninterested in the } \\
\text { lesson }\end{array}$} & $\begin{array}{l}\text { Being interested in the mobile phone (listening to music on the phone, } \\
\text { social media...) }\end{array}$ & 6 & 6 & \multirow{4}{*}{15} \\
\hline & Not following the course & 4 & 3 & \\
\hline & Sleeping during the course & 2 & 4 & \\
\hline & Total & 7 & 8 & \\
\hline \multirow{6}{*}{ Bullying } & Fighting/causing a fight & 5 & 4 & \multirow{6}{*}{12} \\
\hline & Pushing/shaking others & 3 & - & \\
\hline & Building a gang & 1 & 1 & \\
\hline & Shouting/scolding & - & 3 & \\
\hline & Holding for ransom & - & 1 & \\
\hline & Total & 7 & 5 & \\
\hline \multirow{4}{*}{$\begin{array}{l}\text { Harming the } \\
\text { belongings/environment }\end{array}$} & Drawing/writing on the desks & 2 & 2 & \multirow{4}{*}{6} \\
\hline & Writing on the walls (sexual or political content) & 2 & 2 & \\
\hline & Polluting the classroom (throwing trash, etc.) & 1 & 1 & \\
\hline & Total & 2 & 4 & \\
\hline \multirow[t]{2}{*}{ Not obeying the directives } & Untidiness of the appearance (hair, beard, skirt...) & - & 3 & \multirow[t]{2}{*}{3} \\
\hline & Total & - & 3 & \\
\hline \multirow[t]{2}{*}{ Using harmful items } & Smoking & - & 2 & \\
\hline & Total & - & 2 & 2 \\
\hline
\end{tabular}

When Table 4 is examined, it can be seen that the teachers mostly emphasized rudeness (f:14), not fulfilling the responsibilities (f:9), preventing the lesson (f.8) and being uninterested in the lesson (f:7). The behaviors in these themes are interrupting others, swearing, speaking badly, being against the teacher, not bringing the teaching materials to school, making noise and playing with the mobile phone. The teachers who think that interrupting others is mostly made as a joke with each other and for joy stated that swearing is used as a common language between the students. They told that such behavior decreases their motivation and they feel cold towards their profession and explained their ideas as "They swear to everything or everyone. I think their daily language is like that. I walk fast in the corridors, not to hear them; I feel distanced from all courses and the school". T3F. Some sample explanations of the teachers are given below.

"The student makes things which disturb the teacher; he does such things to make the teacher angry. I am not disturbed by phones; the student does not use it. I am disturbed by being loud, so they speak loudly" T1M 
"There is nothing to use as teaching material. They are too arrogant and insolent, they do not accept anything, and they even do not understand their faults. Their actions are like everything is created only for them, they do not fullfil their responsibilities and duties.” T10M

“...they are interested in everything except the teaching material. As they follow the lesson without an aim, they look at my face without any goals. Some of them play with their phones, listen to music or prefer sleeping.” $\mathrm{T} 11 \mathrm{~F}$

According to the ideas of the teachers, behavior harming the environment and belongings of others and bullying are experienced less in the classrooms, while fighting and drawing on the desks and tables are experienced most. One teacher $\mathrm{T} 3 \mathrm{~F}$ who stated that fighting usually occurs at the end of joking, explains it as: "...the dose of jokes has been too much and they apply violence because of this or they create a fighting environment, this disturbs me very much" , two teachers mentioned that the students who do not have anything disturb the others and explained their ideas as: “...they do not bring their school materials and they disturb the ones who bring them, because they do not have anything else to do" T6F and "...there is a mingling of the students who are not interested in the lesson and they disturb the others" T8F.

When Table 4 is examined with regard to the students, it can be observed that the perception is not different from the teachers, as rudeness (f:13), preventing the course (f:12), being uninterested in the course (f:8) and not fulfilling the responsibilities are mentioned most. However, according to the students, rude behavior happens not towards the teacher but towards each other. For example, S2M9 explained this subject as "...there are too many male students in the classroom, they are behaving like bullies and swearing" and S13M12 stated his ideas as "...there is always disrespect and bad talk, our friends are tense and they create a strained environment, making the lesson boring and tense. Sometimes they take or use our belongings without any permission. Especially during exam periods they take our pencils". The students think that behavior related to preventing the course is experienced most in the classroom, while not fulfilling the responsibilities occurs less. The students who think like their teachers about being uninterested in the course, stated that playing with mobile phones and sleeping in the classroom happen the most.Some explanations from the students are given below:

“...when there is no class in another classroom, some students open and close the other classrooms' door for joy to go out or to go downstairs. They even make this more often during some lessons with specific teachers, as these teachers get angry because of this." S9M11

".... since the teacher returns to the classroom 10 minutes later then the bell for the lesson, we usually continue to chat. Actually when the teacher is back, there is little time left until the next break" S15M12

“...listening to music, playing with mobile phones, sharing photos on the phone; sometimes the teachers do the same things, writing something on the board and then opening their Facebook account." S11M11

“...most of our friends do not have teaching materials. Because of this reason they do not take notes or listen to the teacher. They also disturb the ones who follow the teacher.” S7M10

“...not doing homework on time, not participating in course activities, and doing homework or tasks in another lesson are important problems; when the teachers do not intervene, they extend rapidly. We also started doing homework at school." S8M10

According to the explanations of the students, bullying (fighting, shouting, scoulding) and harming the environment/belongings (writing on the desks, walls, etc.) are experienced less compared to other behaviors.

\section{Discussion}

The teachers perceive discipline mostly as a system, self-control and establishing the necessary classroom environment, while the students perceive it as self-control, obeying the rules and respect to himself/others according to the results of this study. When examining related literature, it can be seen that discipline is defined as obeying the rules, controlling yourself, and obeying the social order (Başaran, 2000; Carter ve Doyle; 2006; Eggen \& Kauchak, 2001; Haroun \& O'Hanlon, 1997; Kabaklı Çimen \& Karaboğa, 2015; Nelsen, Lott \& Glenn, 2000; Saygılı \& Gürşimşek, 2008; Wainryb, 2006); preparing an educational environment according to the goals (Akpınar \& Özdaş, 2013;Tunç, Yıldız \& Doğan, 2015; Skaalvik \& Skaalvik, 2009) and a learning process (Neff \& Helwing, 2002; Raby, 2012; Sağnak, 2008). Being systemic as well as controlled and establishing the necessary classroom environment for the students is the basic of effective learning and the social life for teachers whereas fulfilling the responsibilities, behaving according to the environment and obeying the rules is the basic of effective learning and the social life for the students. In this respect, it can be said that the participants emphasized fulfilling the roles and responsibilities expected from them in the school environment while defining discipline. Nowadays, a democratic life, democratic individuals, a democratic culture and human rights are the most emphasized concepts (Lee, 2007; Pala, 2005; Psunder, 2005; Saygılı \& Gürşimşek, 2008). Self-control, obeying the rules and respect are the basic features which the individuals should posses. So, the result could be the need of individuals in accordance with the social life who have positive personality, mental and moral features. 
Another important result gained from this study is that the participants have the same opinion that discipline is not bullying, passivizing and martial law. Bullying, forcing, punishing, controlling, applying strict rules and limitations are behaviors preventing the individuals' internal discipline (Ayas \& Pişkin, 2008; Başaran, 2000; Cotton, 2004;Geiger, 2000; Kabakl1 Çimen \& Karaboğa, 2015; Rosen, 2005; Stephens, Kyriacou \& Tonnessen, 2005; Sheets,2002; Temel, 2005). However, research shows that an implementation of discipline based on bullying and forcing occurs extensively at schools (Ayas \& Pişkin, 2011; Cheraghi \&Pişkin, 2011; Çetin, 2013; Gökyer \& Doğan, 2016; Farmer, 1999; Kabaklı Çimen \& Karaboğa, 2015; Kiptala, Okero \& Kipruto, 2011; Kochenderfer-Ladd \&Skinner, 2002). So, the result demonstrates that discipline is provided like this at the school where the study has been performed. Today, discipline is not only defined as stopping negative behavior and its negative effects but also as helping the individuals to control themselves, realizing their rights and responsibilities and respect (Akpınar \& Özdaş, 2013; Dağlı \& Baysal, 2011;Pattie, 2000; Swinson \& Cording, 2002). Although an implementation based on force and bullying enables public order, it prevents the individuals' meeting of their needs and therefore is not preventing aggressive behavior (Humpreys, 1998). The participants' emphasize that discipline does not mean forcing or controling could be justified from their idea that it is not functional and that the implementations at school are limited in terms of justice, equality and basic rights. The students' statement that it prevents a meeting of their needs as well as the questioning of rights and freedom in their explanations supports this idea.

The gained results indicate that the teachers mostly perceive rudeness, being uninterested in the lesson, interrupting the course and not fulfilling their responsibilities as discipline problems. This result is similar to the results of research made with teachers only (Sarpkaya, 2007; Siyez, 2009; Tunç, Yıldız \& Doğan, 2015; Van Houtte \& Stevens, 2008). An emphasizing of the teachers of behavior negatively affecting the teaching process can be a result of their responsibility of properly carrying out the teaching activities. Not reaching the goals of the class because of any reason can cause problems for the career of the teachers. In this situation, it can be said that the teachers prefer behavior which directly affects their academic activities. The students differ from their teachers, emphasizing behavior such as bullying and forcing as well as harming the belongings and environment. Particularly, fighting and swearing to other are mostly observed between male students (Akpınar \& Özdaş, 2013; Lewis, 2000; Lopez \& Emmer, 2002). The students emphasized that such behavior is against them and that they have been disturbed by this subject. In this respect, it can be said that students primarily describe misbehaviors which are harmful for themselves as discpline problems. A reason why behavior such as harming the belongings/environment, not obeying the directives and using drugs were reported by the students could be that these behaviors are experienced when the teacher is not in the classroom or when students are out of the classroom.

According to the findings of the research, the participants have the same opinion about rudeness, preventing the course, being uninterested in the course and not fulfilling the responsibilities as the most experienced discipline problems. In the related literature, it can be seen that high school students mostly have problems with their lessons (Kyriacou, Avramidis, Hoie, Stephenes \& Hultgren, 2007; Kulaksızoğlu, 2009; Stephens, Kyriacou \& Tonnessen, 2005; Sadık \& İnal, 2011; Siyez, 2009; Tunç, Yıldız \& Doğan, 2015). It is very normal for people to assign different meanings to the content of problems, although they focus on similar problems, since they evaluate the cases from their own perspective. The reason for that is that which behaviors are perceived as discipline problem can change according to the environment, conditions, the individual's behavior and the ones being affected by the behavior (Carotenuto, 2011; Gregory, Cornell \& Fan, 2011, Proter, 2000; Watkins \& Wagner, 2000). However, self-control requires the individual to think about negative effects of behavior before realizing the action not only towards him/herself but also towards others and the environment.

Finally, this research indicats that the perceptions of students and teachers about discipline are positive, they mostly criticized the implementation to provide discipline. Although the students and the teachers have a common perception about behavior which is not relevant at the school or in the classroom environment, it can be seen that the behavior has only been evaluated from one angle. The research indicates that similar problems occur at high schools and that the problems of the adolescents are related to the social relationships between each other as well as their courses. According to these results, recommendations are given below:

- Discussing the negative effects of misbehaviors from different perspectives (on individuals, on others and on the environment) while giving explanations about the disciplinary and behavioral rules in the classroom and at school

- Enhancing the skills of teachers for drawing the attention of the students towards their course, providing motivation and assigning academic duties,

- Providing guidance support to develop the social skills of the students,

- Performing studies where the students can express their mutual expectations, proposals for and critic of discipline and discipline implementation for teachers and students (meeting, workshop, seminar,etc.)

- Arrangements to keep mobile phones out of the classroom. 


\section{References}

Akpınar, B., \& Özdaş, F. (2013). An analysis of discipline problems in high school from the variable of grades. Kastamonu Education Journal (Special Issue), 21(4), 1365-1376.

Atıcı, M., \& Çekici, F. (2009). Comparison of teachers and students' ideas about dealing with misbehaviour in secondary schools. Educational Administration: Theory and Practice, 60(60), 495-522.

Ayas, M., \& Pişkin, M. (2011). Investigation of bullying among high school students with regard to sex, grade level and school type. Elementary Education Online, 10(2), 550-568.

Aygün, A. (2013). The discipline problems that the teachers who work for Anatolian high schools face and the ways to deal with these problems. Unpublished master's thesis, Yeditepe University, İstanbul.

Başaran, İ. E. (2000). Eğitim Yönetimi. Ankara: Umut Yayım Dağııım.

Bear, G. G. (2009). The positive in positive models of discipline. In R. Gilman, E. S. Huebner, \& M. J. Furlong (Eds.), Handbook of positive psychology in schools (pp. 305-321). New York: Routledge.

Carotenuto, M. R. (2011). Pupil misbehaviour and classroom management: the impact of congruence. Unpublished doctoral thesis. University of Southampton, England.

Carter, K., \& Doyle, W. (2006). Classroom management in early childhoodand elementary classrooms. In C. M. Evertson \& C. S. Weinstein (Eds.), Handbook of classroom management: Research, practice, and contem-porary issues (pp. 373-406). Mahwah, NJ: Erlbaum

Çerçi, H. Y. (2009). Discipline approach of the teachers who work in state school. Unpublished master's thesis, Maltepe University, İstanbul.

Çetin, B. (2013). Problems that class teachers faced in the classroom related to undesired behaviors and their solutions. Ahi Evran University Journal of Kirsehir Education Faculty, 14(1), 255-269.

Charles, C. M. (2005). Building classroom discipline. New York: Longman.

Cheraghi, A., \& Pişkin, M. (2011). A Comparison of peer bullying among high school students in Iran and Turkey. Procedia-Social and Behavioral Science, 15, 2510-2520.https://doi.org/10.1016/j.sbspro.2011.04.137

Cotton, K. (2004). School wide and classroom discipline. http://www.nwrel.org/scpd/sirs (05 November 2017).

Cropley, A. (2002). Qualitive research methods: An introduction for students of psychology and education. Riga, Latvia : Zinatne.

Dağl1, A., \& Baysal, N. (2011). The opinions of the second level of primary school teachers about the discipline problems in the classrooms and the discipline techniques used to deal with these problems. Electronic Journal of Social Sciences, 10(38), 61-78.

Demir, M. K. (2011). The Analysis of misbehaviours that teacher candidates do not want to encounter. Buca Faculty of Education Journal, 31, 68-85.

DeSouza, E. R., \& Ribeiro, J. (2005). Bullying and sexual harassment among Brazilian high school students. Journal of Interpersonal Violence, 20(9), 1018-1038. https://doi.org/10.1177/0886260505277731

Ding, M. LI, Y. Li, X., \& Kulm, G. (2008). Chinese teacher's perceptions of sutudents' classroom misbehaviour. Educational Psychology, 28(3), 305-324. https://doi.org/10.1080/01443410701537866

Döker, F. (2006). Negative behaviors and teacher reactions in the classroom of primary school students. Unpublished master's thesis, Yeditepe University, İstanbul.

Doyle, W. (2006). Ecological approaches to classroom management. In C. Evertson \& C. Weinstein (Eds.),Handbook of classroom management: Research, practice, and contemporary issues. New York: Lawrence Erlbaum.

Edwards, D., \& Mullis, F. (2003). Classroom meetings: encouraging a climate of cooperation. Professional School Counseling, 7(1), 20-28.

Eggen, P., \& Kauchak, D. (2001). Educational Psychology. Ohı:Merril Prentice Hall.

Ekici, R., \& Ekici, A. (2014). Comparative study of unwanted student behaviors in primary and secondary schools in classroom management. Journal of EKEV Academy, 59(59), 107-118.

Erol, E. (2014). Classroom management competencies of teachers (Manisa province Sarıöl, Alaşehir towns' model.Unpublished master's thesis, Pamukkale University, Denizli.

Farmer, G. L. (1999). Disciplinary practices and perceptions of school safety. Journal of Social Service Research, 26(1), 
1-38. https://doi.org/10.1300/J079v26n01_01

Geiger, B. (2000). Discipline in K through $8^{\text {th }}$ grade classrooms. Education, 121(2), 383-393.

Gökyer, N., \& Doğan, B. (2016). Administrators' and teachers' views on causes of student misbehaviours. Fırat University Journal of Social Science, 26(1), 93-105.

Gregory, A., Cornell, D., \& Fan, X. (2011). The Relationship of school structure and support to suspension rates for black and white high school students. American Educational Research Journal, 1-31. https://doi.org/10.3102/0002831211398531

Güner, Ü. (2009). The discipline apprehensions and appliances of vocational school teachers Unpublished master's thesis, Yeditepe University, İstanbul.

Haroun, R., \& O'Hanlon, C. (1997). Do teachers and students agree in their perception of what school discipline is? Educational Review, 49(3), 237-250. https://doi.org/10.1080/0013191970490303

Helvacı, M. A. (2010). Sınıfta iletişim ve disiplin oluşturma. Kuram ve uygulamada sınıf yönetimi. Ankara: Anı Yayıncilik.

Humphreys, T. (1998). Disiplin nedir? Ne değildir? (Çeviri. Berat Çelik). İstanbul: Epsilon Yayıncılık.

İnce, B. (2011). Investigation of primary 5 class students? views about the discipline implementation of teachers against behaviors in the classroom. Unpublished master's thesis, Marmara University, İstanbul.

Infantino, J., \& Little, E. (2005). Students' perceptions of classroom behaviour problems and the efectiveness of different disciplinary methods. Educational Psychology, 25(5), 491-508. https://doi.org/10.1080/01443410500046549

Johnson, B., \& Christensen, I. (2004). Educational research: quantitative, qualitative and mixed approaches. Boston: Pearson Education Inc.

Jones, L. S. (1981). Responsible classroom management: Creating positive learningenvironment and solving problems. New York: Ally Bacon.

Kabaklı Çimen, L., \& Karaboğa, Y. (2015). The opinion of managers and teachers on discipline problems at elementary schools. International Journal of Science Culture and Sport. 3.

Kara, N. R. (2008). Investigation of the reactions of 4th and 5th grade primary school teachers to disciplinary disruptive behaviors in the classroom. Unpublished master's thesis, Yeditepe University, İstanbul.

Kayabaşı, C., \& Cemaloğlu, N. (2007). Researching of using teachers' discipline models In the classes in terms of different variables. Ahi Evran University Journal of Kirsehir Education Faculty, 8, 149-170.

Kiptala, W. K., Okero, R. B. O., \& Kipruto, J. (2011). Student's perception of discipline and authority. A case of secondary schools in Taita-Taveta County, Kenya. International Journal of Current Research, 3(8), 68-73.

Kochenderfer-Ladd, B. J., \& Skinner, K. (2002). Children's coping strategies: Moderators of the effects of peer victimization? Developmental Psychology, 38, 267-278. https://doi.org/10.1037/0012-1649.38.2.267

Kulaksızoğlu, A. (1989). The relationship between the ergen-family conflicts and the attitudes of the mothers and ergenen problems. Journal of Marmara University Education Sciences, 1, 71 - 87.

Kuzu, H. (2007). Implementation status of strategies for teachers to prevent and change unwanted behaviors. Journal of National Education, 175, 57-66.

Kyriacou, C., Avramidis, E., Hoie, H., Stephenes, P., \& Hultgren, A. (2007). The development of student teachers views on pupil misbehaviour during an initial teacher training programme in England and Norway. Journal of Education for Teaching, 33(3), 293-307. https://doi.org/10.1080/02607470701450288

Lee, S. J. (2007). The relations between the student-teacher trust relationship and school success in the Korean middle schools. Educational Studies, 33(2), 209-216. https://doi.org/10.1080/03055690601068477

Lewis, R. (2000). Classroom discipline and student responsibility: The students' view. Teaching and Teacher Education, 17(3), 307-319.

Lewis, R. (2001). Classroom discipline and student responsibility: The students' view. Teaching and Teacher Education, 17(3), 307-319. https://doi.org/10.1016/S0742-051X(00)00059-7

Lewis, R., Romi, S., Qui., X., \& Katz, Y. (2005). A comparison of teachers' classroom discipline in Australia, China and Israel. Teaching and Teacher Education, 21, 729-741. https://doi.org/10.1016/j.tate.2005.05.008 
Lopez, V. A., \& Emmer, E. T. (2002). Influences of beliefs and values on male adolescents' decision to commit violent offenses. Psychology of Men \& Masculinity, 3, 28-40. https://doi.org/10.1037/1524-9220.3.1.28

Mainhard, M. T., Brekelmans, M., \& Wubbels, T. (2011). Coercive and supportive teacher behaviour: Within-and across-lesson associations with the classroom social climate. Learning and Instruction, 21(3), 345-354. https://doi.org/10.1016/j.learninstruc.2010.03.003

Manning, M. L., \& Bucher, K. T. (2007). Classroom management: models implementations and cases. USA: Pearson Education, Inc.

Marlow, B. A., \&Page, M. L. (1998). Creating and sustaining the constructivist classroom. California: Corwin Pres Inc.

Miles, M. B., \& Huberman, A. M. (1994). Qualitative data analysis. An expanded sourcebook.Los Angeles, London, New Delhi, Singapore, Washington DC: Sage Publications.

Mitchell, M., \& Bradshaw, C. (2013). Examining classroom influences on student perceptions of school climate: The role of classroom management and exclusionary discipline strategies. Journal of School Psychology, 51(5), 599-610. https://doi.org/10.1016/j.jsp.2013.05.005

Moreno, J. A., Cervelló, E., \& Martínez Galindo, C. (2007). Perception of discipline acoording to gender, type of school, sport activity and interest in physical education in Spanish students. International Journal of Applied Sports Sciences, 19(2), 35 - 49.

Neff, K. D., \& Helwig, C. C. (2002). A constructivist approach to understanding the development of reasoning about rights and authority withincultural contexts. Cognitive Development, 17(3-4), 1429-1450. https://doi.org/10.1016/S0885-2014(02)00126-0

Nelsen, J., Lott, L., \& Glenn, H. S. (2000). Positive discipline in the classroom, (3. Edition), USA, Prime Publishing.

Öz, E. Z., \& Sadık, F. (2015). Secondary school teachers and students' views and suggestions regarding discipline problems and strategies to cope with them. The Journal of Academic Social Science, 3(18), 151-189.

Pala, A. (2005). Sınıfta istenmeyen öğrenci davranışlarını önlemeye dönük disiplin modelleri. Manas University Journal of Social Sciences, 13, 172-179.

Pattie, L. F. Y. Y. (2000). Personal and social education and teacher development in Hong-Kong. Pastoral Care in Education, 18(2), 42-46.https://doi.org/10.1111/1468-0122.00160

Patton, M. Q. (2002). Qualitative research evulation methods. California: SAGE.

Polat, S., Kaya, S., \& Akdag, M. (2013). Investigating pre-service teachers' beliefs about classroom discipline. Educational Sciences: Theory and Practice, 13(2), 885-890.

Proter, L. (2000). Behavior in schools theory and practice for teachers. Philadelphia: OpenUniversityPres.

Psunder, M. (2005). Identification of discipline violations and its role in planning corrective and preventive discipline in school. Educational Studies, 31(3), 335-345. https://doi.org/10.1080/03055690500236936

Raby, R. (2012). School rules. Obedience, discipline and elusive democracy. University of Toronto Pres. Canada.

Rahimi, M., \& Hosseini, K. F. (2012). EFL teachers' classroom discipline strategies: The students' perspective. Procedia-Social and Behavioral Sciences, 31, 309-314. https://doi.org/10.1016/j.sbspro.2011.12.060

Rogers, W. A. (1983). Decisive discipline. In M. Lovegrove \& R. Lewis (Eds.). Classroom discipline (pp. 43-66). Sydney: Longman Cheshire.

Rosen, L. (2005). School discipline. USA: Corwin Press.

Sadık, F. (2002). İlköğretim I.aşama sınıf öğretmenlerinin sınıfta gözlemledikleri problem davranışlar. Cukurova University Faculty of Education Journal, 10(10), 1-23.

Sadık, F., \& Aslan, S. (2015). An investigation of the elementary school Classroom teachers' views regarding discipline problems. Turkish Studies, 10(3), 115-138.

Sadık, F., \& İnal, U. (2011). Ortaöğretim kurumlarında karşılaşılan disiplin problemlerinin öğretmen görüşlerine göre değerlendirilmesi (Adana ili örneği). Paper presented at the 20. National Conference on Educational Science, Burdur, Turkey, September. (Retrieved from https://scholar.google.com.tr/scholar.

Sağanak, M. (2008). The discipline styles of high school teachers. Ahi Evran University Journal of Kırşehir Education Faculty, 9(2), 17-22.

Sarpkaya, P. (2007). The reasons of disciplinary problems at state high schools according to the opinons of 
administrators, students, teachers and family members. Pamukkale University Journal of Education, 2(22), $110-121$.

Saygll, G., \& Gürşimşek, I. (2010). Student's perceptions concerning with misbehaviours in classroom. Buca Faculty of Education Journal, 23, 152-159.

Sheets, R. H. (2002). You're just a kid that's there- chicano perception of disciplinary events. Journal of Latinos\& Education, 1(2), 105-122. https://doi.org/10.1207/S1532771XJLE0102_3

Siyez, D. M. (2009). High school teachers' perceptions of and reactions towards the unwanted student behaviors. Pamukkale University Journal of Education, 1(25), 67-80.

Skaalvik, E. M., \& Skaalvik, S. (2007). Dimensions of teacher self-efficacy and relations with strain factors, perceived collective teacher efficacy, and teacher burnout. Journal of Educational Psychology, 99, 611-625. https://doi.org/10.1037/0022-0663.99.3.611

Stephens, P., Kyriacou, C., \& Tonnessen, F. E. (2005). Student teachers view of pupil misbehaviour in classrooms: a Norwegian and an English setting compared. Scandinavian Journal of Educational Research, 49(2), 203-216. https://doi.org/10.1080/00313830500049004

Stephenson, J., Linfoot, K., \& Martin, A. (2000). Behaviours of concern to teachers in the early years of school. International Journal of Disability, Development and Education, 47, 225-235. https://doi.org/10.1080/713671118

Swinson, J., \& Cording, M. (2002). Assertive discipline in a school for pupils with emotional and behavioural difficulties. British Journal of Special Education, 29(2), 72-75. https://doi.org/10.1111/1467-8527.00243

Temel, A. (2005). Okulda ve sinıfta disiplin. Gençlik ve Rehberlik Sempozyumu. Maltepe Üniversitesi, 27-28 Haziran, İstanbul (Retrieved from https://scholar.google.com.tr/scholar)

Tomal, D. R. (2001). A Comparison of elementary and high school teacher discipline styles, American Secondary Education, 30(1), 38-45.

Tratwijk, V. J., Brok, D. P., Veldman, I., \& Wubbels, T. (2009). Teachers' practical knowledge about classroom management in multicultural classrooms. Teacher and Teacher Education, 25, 453-460. https://doi.org/10.1016/j.tate.2008.09.005

Tunç, B., Yıldız, S., \& Doğan, A. (2015). Discipline problems in vocational high school, causes and solutions: a case study. Abant Izzet Baysal University Journal of Education Faculty, 15(2), 384-403.

Van Houtte, M., \& Stevens, P. A. J. (2008). Sense of futility the missing link between track position and self-reported school misconduct. Youth and Society, 2, 245-264. https://doi.org/10.1177/0044118X08316251

Vitto, J. M. (2003). Relationship-driven classroom management: Strategies that promote student motivation. Thousand Oaks, CA: Corwin Press.

Wainryb, C. (2006). Moral development in culture: Diversity, tolerance, and justice. In M. Killen \& J. G.Smetana (Eds.), Handbook of moral development(pp. 211-240). Mahwah, NJ: Erlbaum.

Watkins, C., \& Wagner, P. (2000). Improving School Behavior, London: Paul Chapman Publishing Ltd.

Yavuzer, H. (2003). Çocuğu tanımak ve anlamak. İstanbul: Remzi Kitabevi Yayıncılık.

\section{Copyrights}

Copyright for this article is retained by the author(s), with first publication rights granted to the journal.

This is an open-access article distributed under the terms and conditions of the Creative Commons Attribution license which permits unrestricted use, distribution, and reproduction in any medium, provided the original work is properly cited. 